\title{
特許出願 公告及ひ特許拔孪
}

\section{特許会告 拔花}

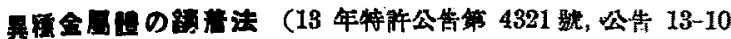

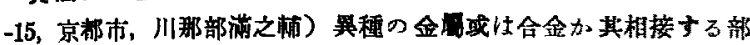

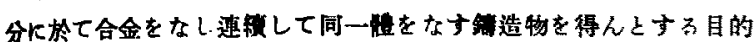

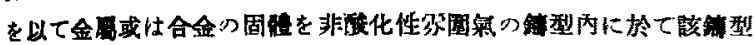

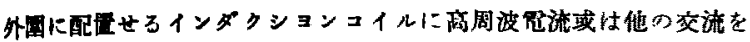

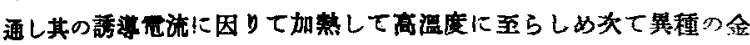

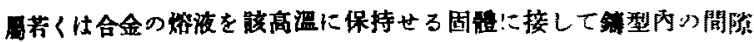

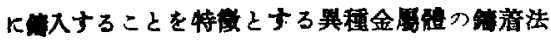

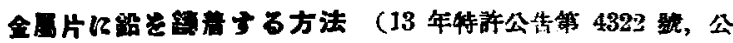

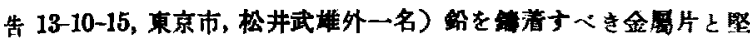

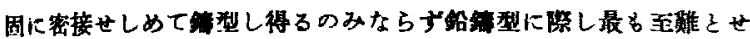

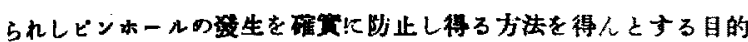

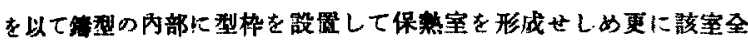

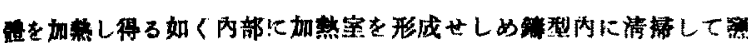

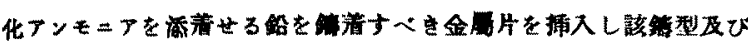

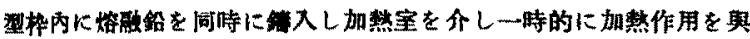

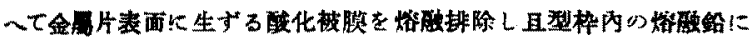

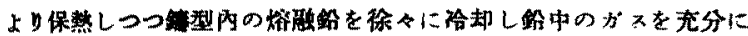

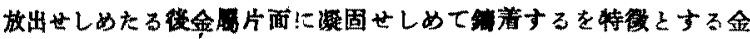

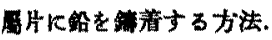

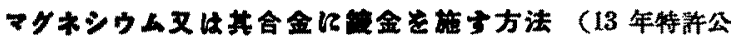

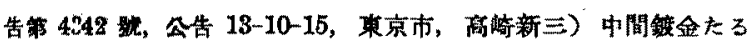

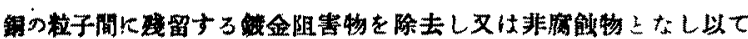

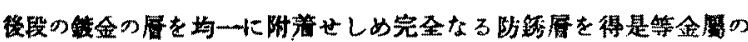
海水其他の洨又はガ スに俄る磨领を防止世しめんとする目的を以て

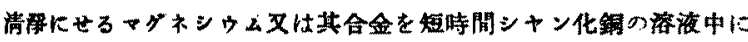

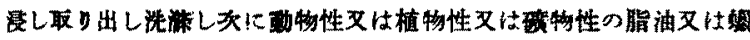

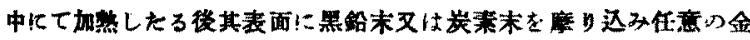

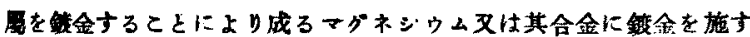
方法.

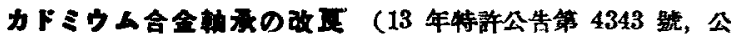

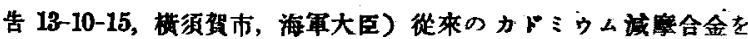

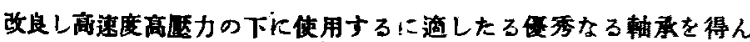

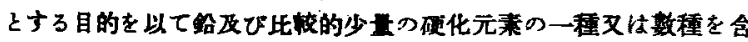

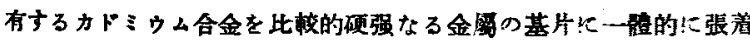
して成る娍庵外被を借一たる轴承。"

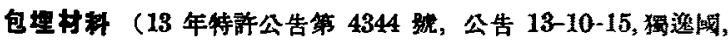

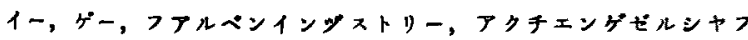

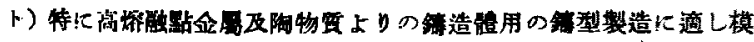

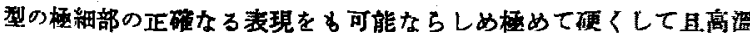

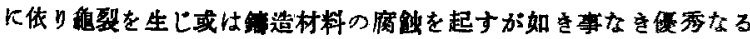

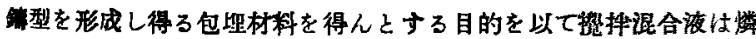

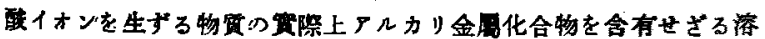

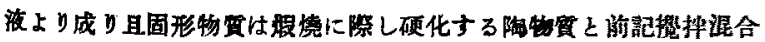

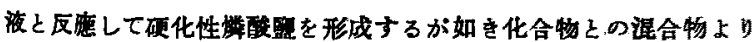

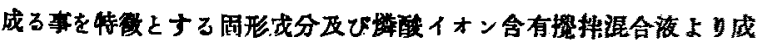
万包埋材料.

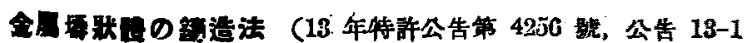

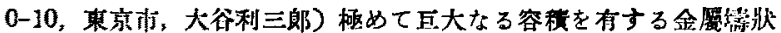

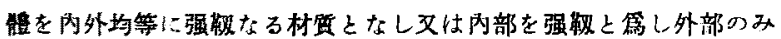

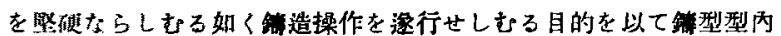

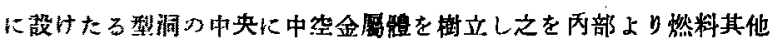

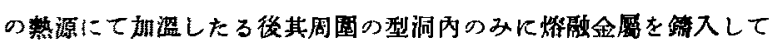

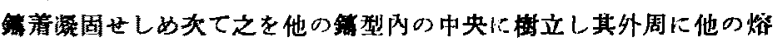

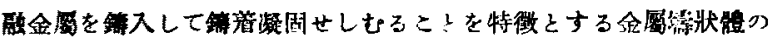
籍造法.

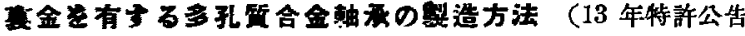

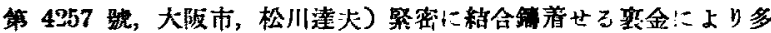

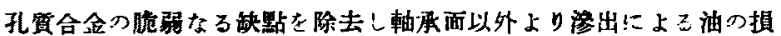

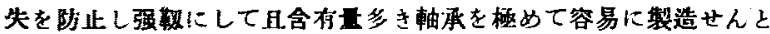

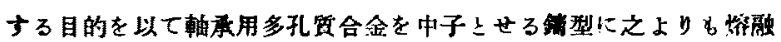

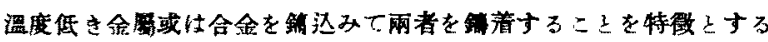

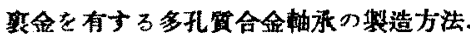

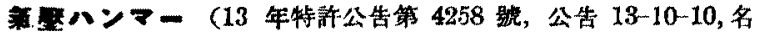

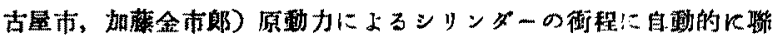

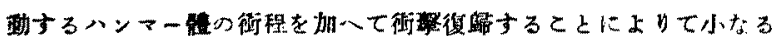

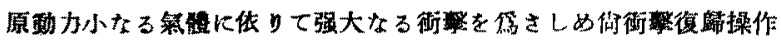

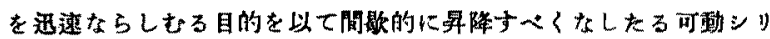
ンダー內に於て中部に俩壁を設け其の上位及び下位に固定ピストン

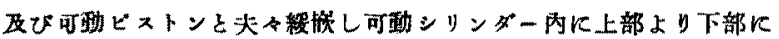

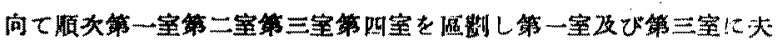

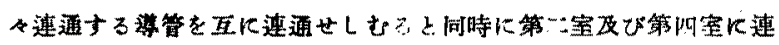

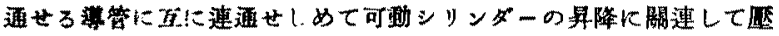

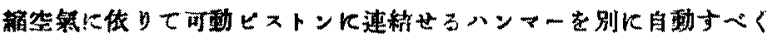
なしたる氣壁ハンマー

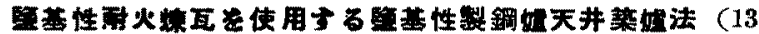

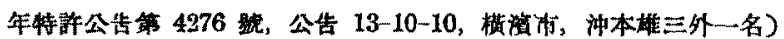

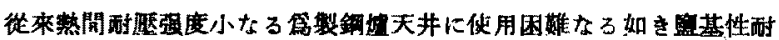

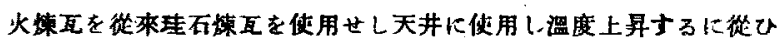

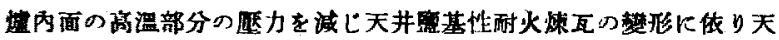

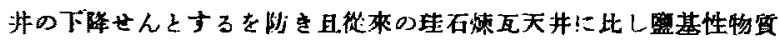

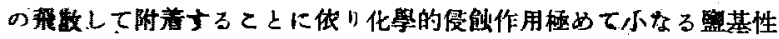

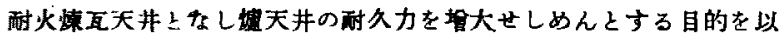

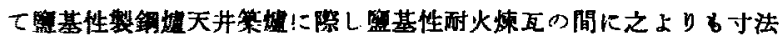

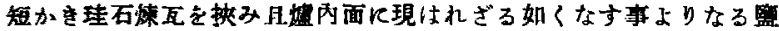

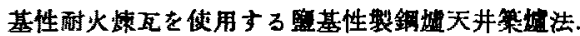

珪瑟ーアルミニウムー武合金を全成分又は主成分として

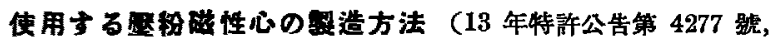

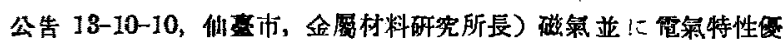

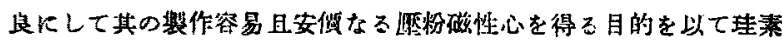

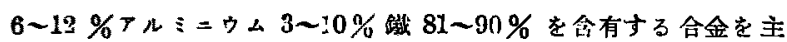

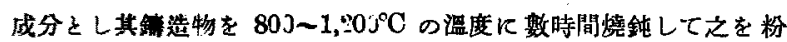
碎したろ素ーアルミニウム钱合俞を全成分又は主成分として使用

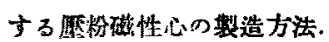

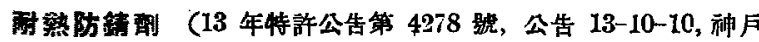

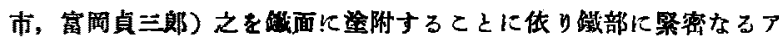

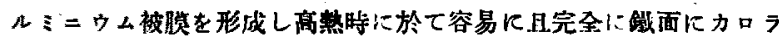




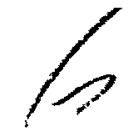

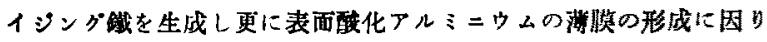

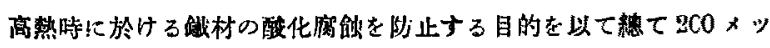

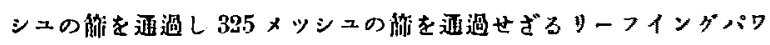

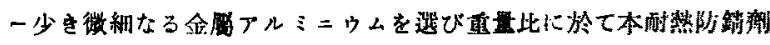

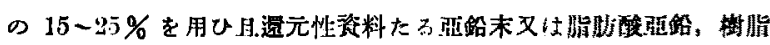

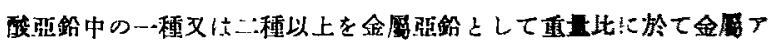

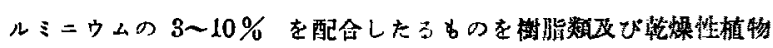

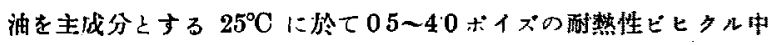

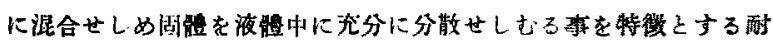

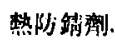

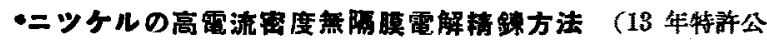

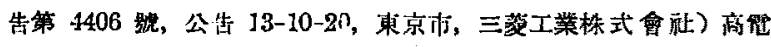

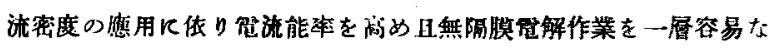

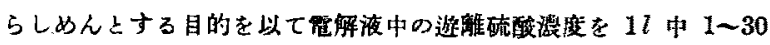

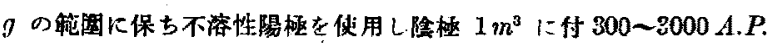

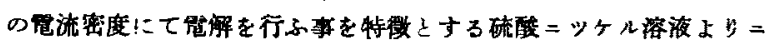

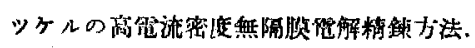

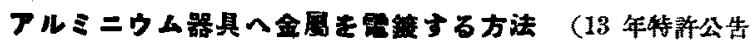

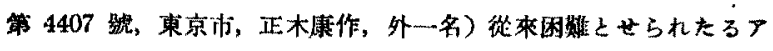

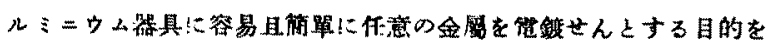

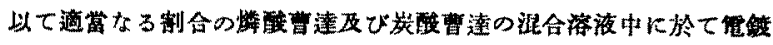

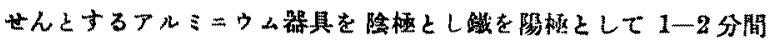

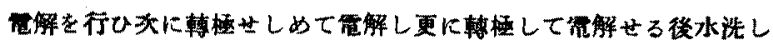

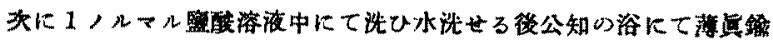

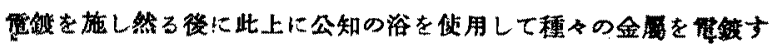

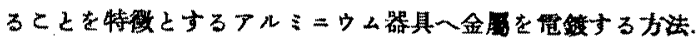

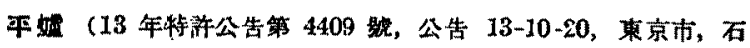

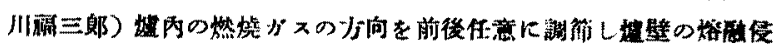

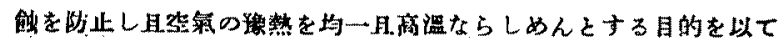

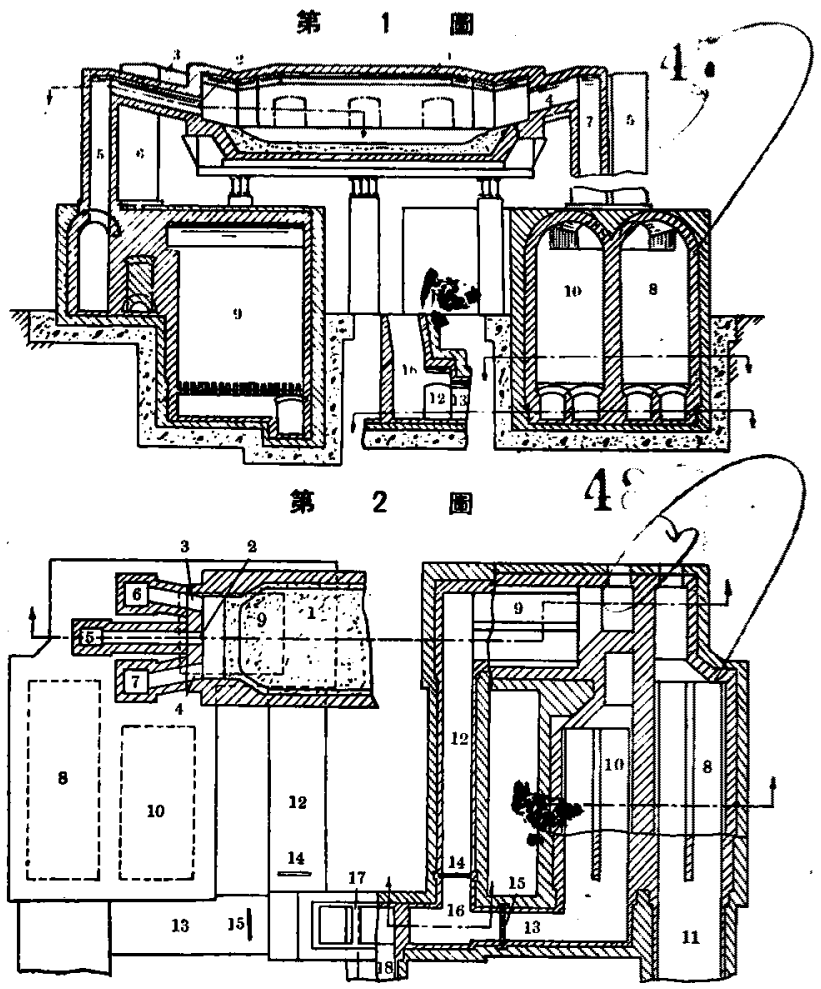

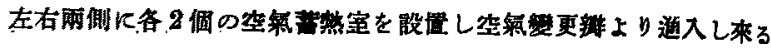

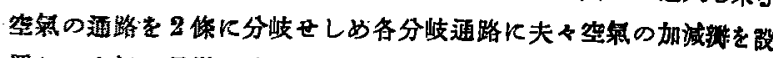

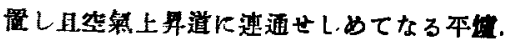

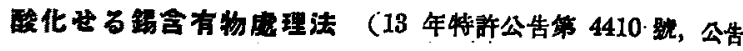

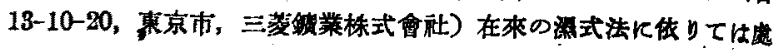

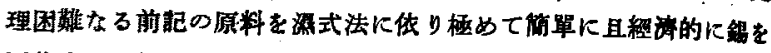
回收する目的を以て酸化せる錫含有物を $400^{\circ} \mathrm{C}$ 以上にて酸化堵㛘

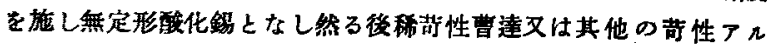
カりー液を以てォートクレーブ內にて医力 40 氣㯲內外温度 $250^{\circ} \mathrm{C}$

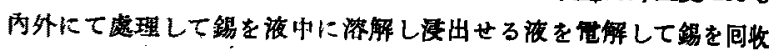
する方法。

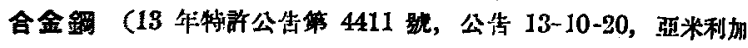

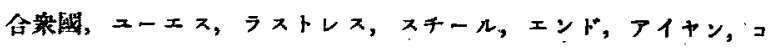

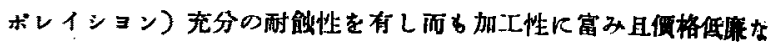

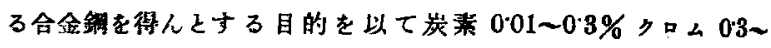
$2 \%$, 銅 $015 \sim 5 \%$, 珪素 $025 \sim 6 \%$, 橉 $0(7 \sim 1 \%$ を含有し破部 は跳及不絋物上り成る合金銅。

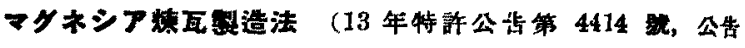

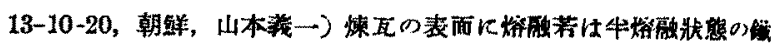

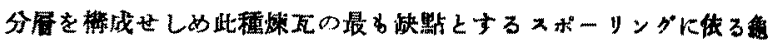

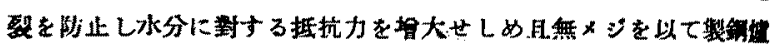

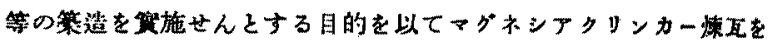

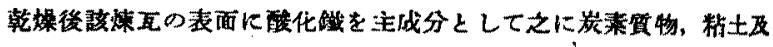

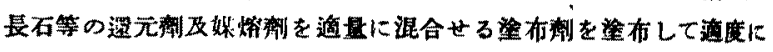

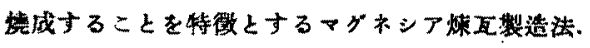

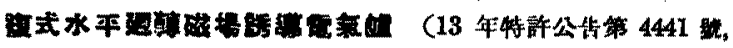

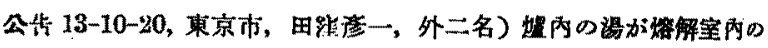

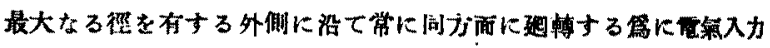

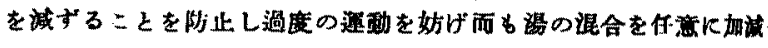

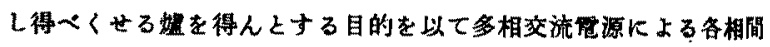

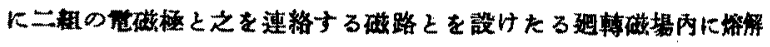

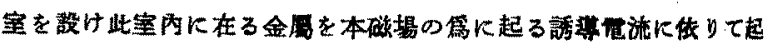

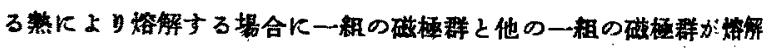

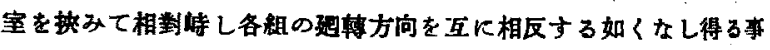

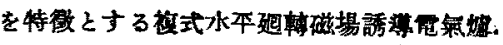

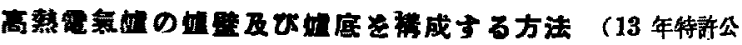

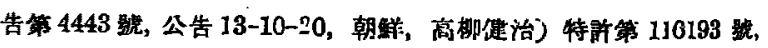

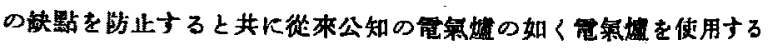

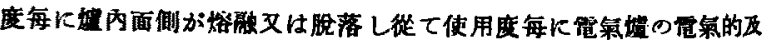

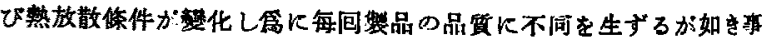

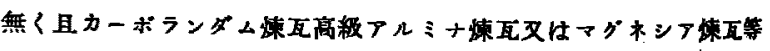

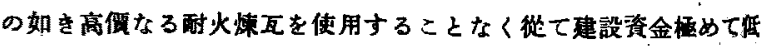

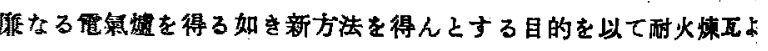

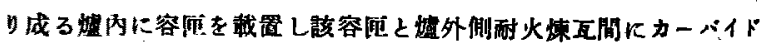

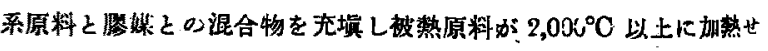

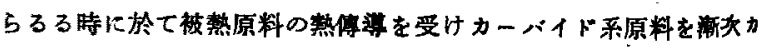
ーバイド化し且該カーパイド化されたる物質をタール等の如きカー

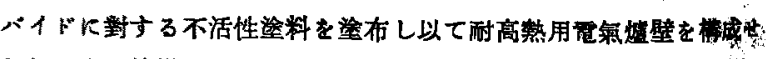

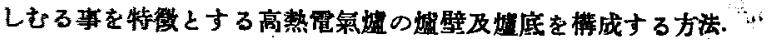

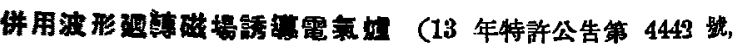

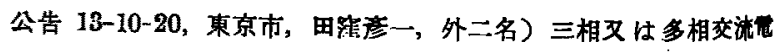

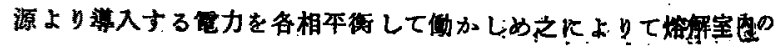




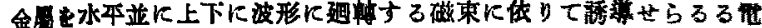

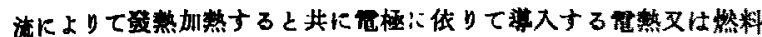

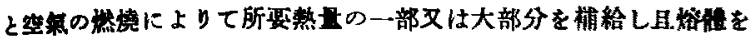
水平並に上下に撒拌する蝹を得儿とする目的を以て多相交流電源に

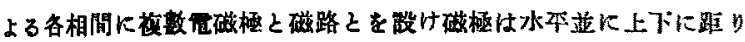

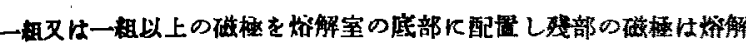

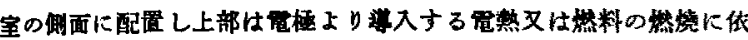
りて成生ナる整に依りて蛊內に必娶なる熱の一部及は大部分を㭪給 する如くし依て生ずる磁束は上下並に水平に波形に透轉拈行する如

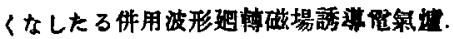

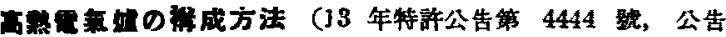

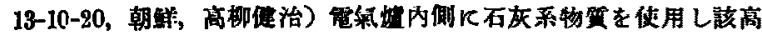

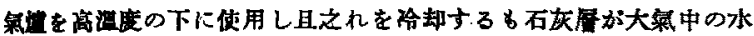

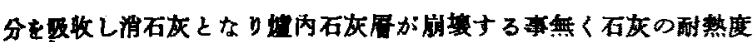

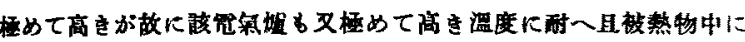

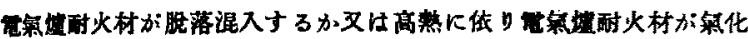

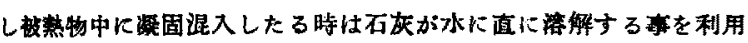

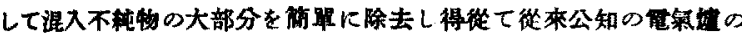

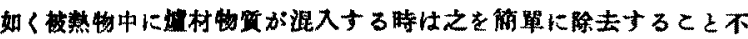

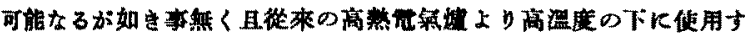

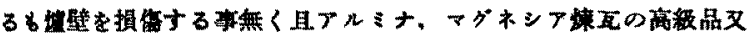

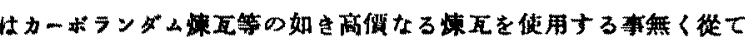

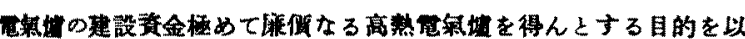

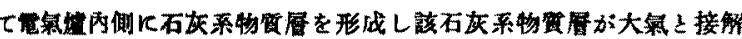
する部分にビッチ，タールヌはアルミナ，マグネシアヌは珪酸等の

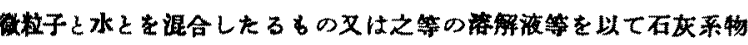

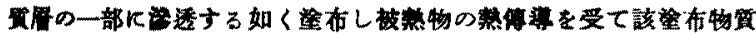

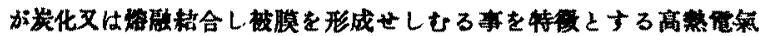
蛅の權成方法

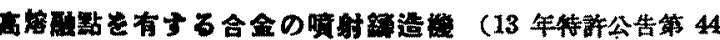

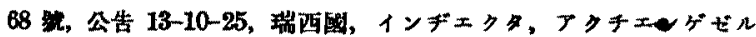

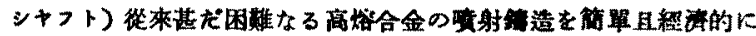

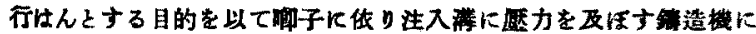

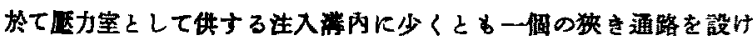

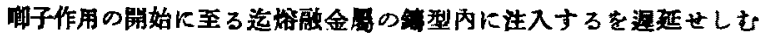

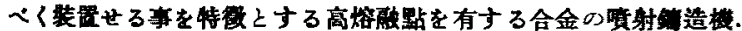

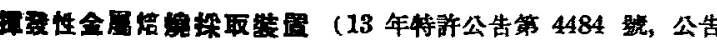

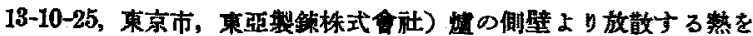

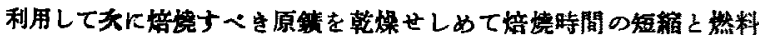

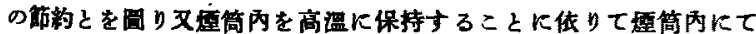

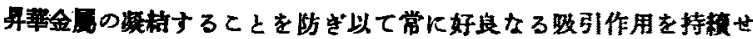

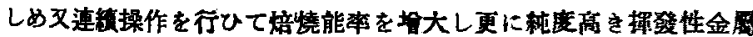

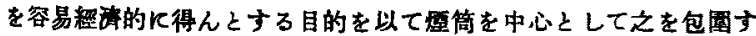

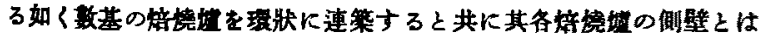

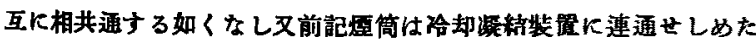

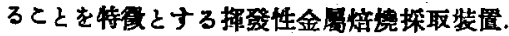

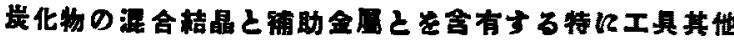
工作用硬合金の

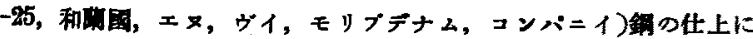

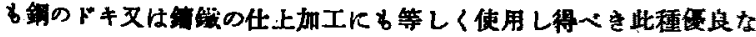
了硕合金を得んとする目的を以て珪素，千タン，ヂルコニシム，タ

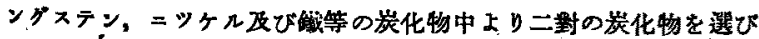

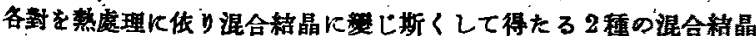

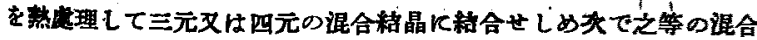

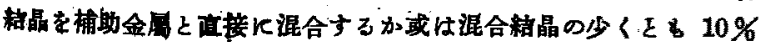

を他の炭化物及び㭪助金屡と混合し加熱して固稍せしむるととを特

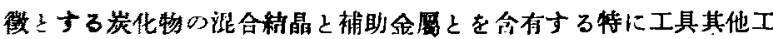
作用硕公金の製造法.

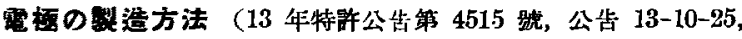

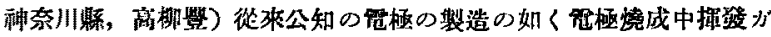

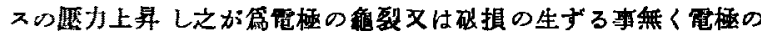
中心部附近に於て外周部附近上り身孔度少なる如き不合理を生ずる 舞々䲞んて外周部附近の氣孔度が中心部附近の氮孔度上り少なる 如くし從て中心部附近より外周部附近が機械的强度强く且害算度。

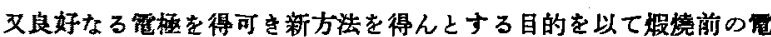

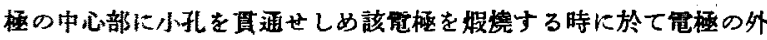

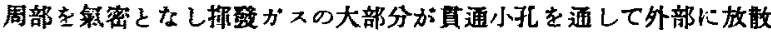
ナる如くしたる奄極の製造方法。

\section{特 許 拔 莝}

䅨䛨

126437

126448

126292

$126 \cdot 81$

126241

$1263 \mathrm{Cs}$

126237

126316

126339

126437

126232

126357

126301

126300

126310

1:6426

126455

126560

120463

126486

126570

126527

126528

126480

126464

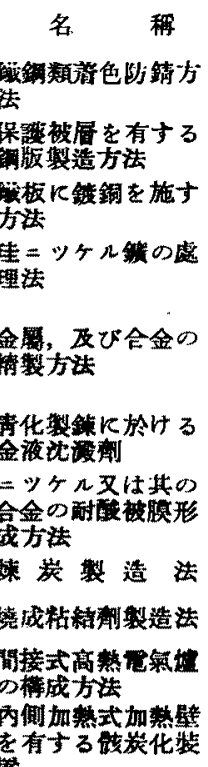
有与了领炭化婓

アルミニウム合全

紛鋮合金製逶方法 鉛銅合金製造方法 矮戻硬化性銅合金

綂蜩

銅 合 金

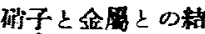
合方法

食整水儿耐ゆる グネシウム合金 烧属槽に於的3

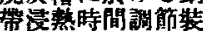

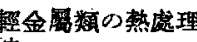
法

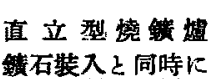

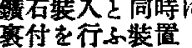

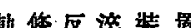

壦原䂗性銅合全

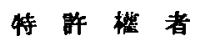

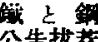

公告拔萃

第21年第10號

中 锉 吾 -

津 村 芳二咅)

第24年第 4 暍

$$
\text { * 武 (外二告) }
$$

日本ニッタル

パッフアロ, メレク トリック、フフー* 一スコルポレイシ

松川造夫

" 第 7 號

" 第 7 號

第 7 㩆

日本火工株式會藏 ナ 根本内。記ナ。 野貞治郎 高 楖 健 治 第24年第6 號

テオドーn,

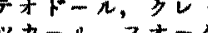

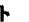

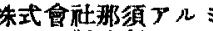
ニウム製造所

松川洼夫" 5 跴 松川洼夫”第 5 號

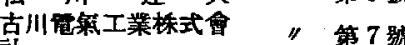
住友機珹製作怢式會 " " 第7 號 古川電氢工業株式會“" 的坂 誏一 佳友金䖯工業株式會 就

”第 7 號 ”第 7 號 海 野 幸 保 第24年第 7 號 ドイッチェ：゙ール ド, ウンドジル ル,シャイデアンス タルト,フォルマル スレッスラー スレッスラー

第 8 躆 " 第 8 號 ソシェテ,デ,ジーフ ールノー・ドウ, 第 24年第 8 號

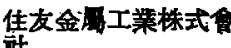
第24年第 7 號 